\title{
Ethical Conduct and Perceptions of Public Probity in Britain: the Story so Far
}

\author{
JAMES L. NEWELL
}

'There can be no greater threat to the permanence of our democracy and our democratic liberties than that the public should get it into their heads that national or local government is irregular, subject to improper influences or even corruption and bribery’ (Herbert Morrison , 1947)

\section{Introduction}

If corruption is significant for the welfare of less developed countries (where bribery can help to perpetuate relative states of lawlessness and insecurity which in turn act as brakes on economic development), then its potential significance is hardly less for the older established democracies of places like western Europe, simply because of what is at stake - or might be at stake. Della Porta and Vannucci have argued, with respect to liberal democratic regimes, that corruption in a democracy is in effect the corruption of a democracy, meaning that where corruption occurs in these regimes, its effects, or potential effects, are such as to undermine, or considerably weaken their claim to be 'democratic' at all.

However, it is important to distinguish between two 'levels' of impact in the sense that one can have corruption that is exposed and corruption that is not exposed, and the effects of the exposure of corruption will not be the same as the effects of the underlying phenomenon. Moreover, the exposure of corruption is only likely to have any significant effect if it provides the basis for scandal where the latter requires: 1) the transgression or presumed transgression of values, norms or moral codes; 2) by certain people whose positions make them 'scandal-prone'; where 3) 'non-participants' disapprove of the actions/events/incidents and articulate their disapproval by publicly denouncing what has happened, or is presumed to have happened.

The analysis of moral codes and of what publics expect of politicians and public officials is therefore crucial for an understanding of the significance of corruption in modern democracies. It is crucial for at least two other reasons besides. First, whatever else it might mean, the term 'corruption' refers to an infringement of rules - where a 'rule' is a criterion of behaviour that indicates right and wrong ways of doing things; is something that can only exist in virtue of social interaction, and is something whose infringement is to some greater or lesser degree morally condemned in the group whose social existence gives rise to it. Therefore, to describe given acts as 'corrupt' is to condemn them as illegitimate according to the standards of one's own group or at least the group with which one identifies - which in turn means that we cannot know what counts as corruption unless we know something about the moral codes of the group to 
which the person seeking to apply this label belongs. ${ }^{1}$

Third, democracies are regimes that are by definition responsive to public opinion - but on the other hand, public opinion is not an exogenous variable as far as the actions and initiatives of governments are concerned: publics take their cues in terms of their attitudes and policy preferences from what agenda-setting authorities define for them as 'problems' and from what they define for them as viable means of addressing those problems. So public attitudes and moral codes are central also to how authorities respond to the exposure of corruption and similar forms of misconduct. On the one hand, authorities' responses are significantly influenced by public reactions; on the other hand, these responses themselves tend to define misconduct as a 'problem' worthy of attention and thus to trigger certain moral reactions. So the problem of responding to corruption and misconduct is to a very large extent a problem of the management of public concerns - as Herbert Morrison well understood. Indeed, it may not be going too far to suggest that political elites are in this area driven less by the desire to ensure that the behaviour of those in the public domain is in fact clean (as they understand 'clean') than by the desire to ensure that it is perceived to be clean. After all, anti-corruption measures may be inconvenient in all sorts of ways and their effectiveness must (given that corruption is a clandestine activity) always be attended by a degree of uncertainty. On the other hand, public disapproval of those in authority undermines that authority by definition; and in an age of mediated communication it is a risk that can be averted only if the authorities' attention to it is constant. There can be little doubt that it was these two conflicting sets of imperatives that lay at the base of what was for many years the dominant strain in the strategy of British political elites for dealing with the exposure of corruption and misconduct, namely, to treat the perpetrators as 'rotten apples': to subject, that is, identified cases to investigations that dealt with the offenders - but that also repeatedly insisted on 'the general integrity of institutions and the robustness of the procedures involved in dealing with the offences' (Doig, 2003).

Taking its point of departure from these reflections, this paper will discuss, with reference to the British case:

1) what has been responsible for growing levels of concern about corruption and the standards of conduct of public office holders since the beginning of the 1990s;

2) what we know about public perceptions, especially: the kinds of behaviour the public sees as acceptable and unacceptable on the part of public office-holders; how far the public believes that the behaviour of public office-holders is, in fact, acceptable or unacceptable; how far the public believes that public office-holders are effectively held responsible and accountable for their conduct;

3 ) the role in perceptions of the policy response that has been influenced by 1) and 2).

\footnotetext{
${ }^{1}$ The centrality of moral codes to what counts as corruption remains even in the case of those definitions of the term that appear to render it independent of such codes: for example, principal-agent definitions - of the most widely used definitions seemingly the most independent of public attitudes - are independent only in appearance, for they make the difference between corrupt and non-corrupt actions turn on the principal's - socially informed - decisions about the interests and preferences the agent is to be required to advance.
} 


\section{Growing levels of concern}

Cross-nationally, the beginning of the 1990s appeared to mark the start of a growing salience of corruption and misconduct as an issue. The following years were marked by a number of high-profile scandals - including Tangentopoli in Italy; the various allegations of 'sleaze' that played a prominent role in the downfall of the Conservatives in Britain; the party finance scandal that led to the disgrace of Helmut Kohl in Germany; the resignation, in 1999, of the entire EU Commission in the wake of publication of evidence of fraud, corruption and mismanagement at senior levels. Transparency International, the non-governmental organisation created to fight corruption, began in 1993 (Harrison, nd: 2). There was growing academic attention to the issue: inserting the expression 'political corruption' into the search box of the British Library's integrated on-line catalogue throws up 1,266 items - of which no fewer than 1,073 were published in 1990 or later. Impressionistically, then, the period since 1990 seems to have been marked by growing levels of public concern - but before considering their possible causes, let us establish more firmly, for the British case, the actual existence of these growing levels. At least three sets of indicators seem to suggest themselves: survey data; media reports of allegations of misconduct; committees of enquiry and government initiatives of various kinds. With this is mind we begin by considering Transparency International's Corruption Perceptions Index (CPI).

Figure 1 shows CPI scores for the UK from 1995 (the year the CPI was launched) through to 2006. As is widely known, the CPI is a 'poll of polls' published annually on the basis of an analysis of existing polls of international business interests and financial journalists and which thus presents a picture of how international business perceives levels of corruption in the countries surveyed. A score of 10 means 'an entirely clean country while zero equals a country where business transactions are entirely dominated by kickbacks, extortion etc.' (Transparency International, 1995: 3). As the press release, launching the first set of CPI scores pointed out, 'perceptions may not be a fair reflection on the state of affairs, but they are a reality' (Transparency International, 1995: 3). From 1995 to 2001 there is a clear downward trend in the UK's rating - from 8.57 to 8.3 - with the score settling back at a higher average of 8.64 in the subsequent period.

Media reports tell a similar story. We used the LexisNexis Professional on-line database - which contains full-text articles from UK national and local newspapers - to explore the occurrence, in Guardian headlines, of words such as 'corrupt' and 'bribe' and their derivations ('corruption', 'corrupting', 'corrupted', 'bribery', 'bribed' etc.) over the 22 years from 1984 to 2005. The Guardian is a left-of-centre newspaper with a largely middle-class readership having above-average levels of educational attainment. As such it has a reputation for avoiding the sensationalism of some of the more popular dailies while being sensitive to matters of probity in public life. Figure 2 presents the results. There is a clear upward trend throughout the period with a peak of 359 relevant headlines in 1997. This was the year of the general election in which the Conservatives sought to defend themselves against allegations of 'sleaze' - an umbrella term covering acts of sexual impropriety, misuse of office, and material greed - from a position of weakness which the then Prime Minister (PM) had created for them by calling for a reassertion of 
family values and private morality in a 'back-to-basics' campaign launched in October 1993. The subsequent revelation of conduct on the part of prominent Conservatives that was clearly at variance with what the PM was claiming was the party's core values could not, in an election year, have been other than thrust centre stage by journalists for many of whom the unveiling of official hypocrisy is seen as a way of pursuing their calling as guardians of the public interest (Thomoson, 2000; Moncrieff, 2005). It is interesting that the 1997 peak coincides exactly with the CPI trough shown in figure 1. Following an apparent decline in press attention to corruption and related matters in the early years of the Labour government that took over from the Conservatives, there has since then been another revival of interest.

Press attention is a good indicator of popular concerns and public reactions to acts of official misconduct because newspapers have a financial interest in covering matters, and in covering them in a way, that will have an echo with their readers. If it is true that media organizations are agenda-setters, providing publics with windows on the world, then it is also true that they cannot survive to play this role unless they successfully echo back to their audiences, their audiences' own core values and key assumptions. So newspapers faithfully reflect, as well strongly shape public opinion.

Finally, official measures to combat corruption and misconduct must also be judged as good indicators of levels of public concern in the British case simply because of the way they have been so closely tied to specific scandals and so obviously driven by the desire 'to mollify public concern rather than introduce effective reforms' (Doig, 1996: 44 ) - as descriptions of the most high-profile of the official initiatives taken in the postwar period soon reveal.

- In 1948, the Lynskey Tribunal was established following allegations that John Belcher, a junior minister at the Board of Trade, had abused his position in exchange for gifts and hospitality from Sidney Stanley, a businessman who had apparently received thousands of pounds from football pools firms to obtain influence with the minister (Day, 2000: 8; Paterson, 2000: 47). Its findings forcing the minister to resign, Lynskey led to the establishment of a parliamentary 'Committee on Intermediaries' to examine 'how far persons are making a business of acting as... intermediaries between Government Departments and the public, and to report whether the activities of such persons are liable to give rise to abuses...' While the committee recommended that departments constantly 'overhaul their control system', it concluded that disreputable intermediaries were 'few in number' and their activities 'not on such a scale that a general restriction on them [was] justified' (Committee on Intermediaries, 1950).

- In 1969, a Commons Select Committee on Members' Interests was established after an MP, Gordon Bagier, had initially denied and then been forced to admit being in the pay of a PR firm working for the Greek military government, and it was revealed that the firm had told the Greeks that it 'had a British MP lobbyist working behind the scenes to influence other MPs' (Doig, 1984: 215). Called to examine the rules and practices concerning the declaration of MPs' interests, the Select Committee rejected the idea of a register of members' interests and its report was, in any event, shelved. 
- In the early 1970s, a series of revelations, triggered by a petition for bankruptcy filed by the architect John Poulson in 1972, led to the Redcliffe-Maud inquiry, the Salmon inquiry and two parliamentary inquiries. In essence, Poulson cultivated contacts in wide areas of public life in order systematically to corrupt them in the pursuit of building and design contracts, and the investigations that his bankruptcy precipitated led to the downfall of a string of local councilors and civil servants, and three MPs including a government minister. Redcliffe-Maud, set up in October 1973, 'to look at situations in which councilors or officers might be involved in conflicts of interest, and at qualifications for council membership' (Doig, 1984: 146) made a number of recommendations none of which were debated by Parliament, and only some of which were implemented - but then not monitored for effectiveness (Doig, 1996: 44). Salmon too produced a lengthy series of recommendations whose implementation was regularly resisted by the government of the day. The first parliamentary enquiry, in 1974, established a register of MPs financial interests - but then left it up to MPs themselves to decide what interests were relevant for registering and subsequently showed itself reluctant to act as the Commons' policeman in response to media allegations (Doig, 1996: 44). The second enquiry, established in 1976 to investigate the conduct of the three MPs caught up in the Poulson scandal, found all to have fallen short of standards of conduct reasonably to be expected - but, with Leader of the Commons, Michael Foot, urging the House 'not to act like a sanctimonious lynch mob', MPs refused to do anything more than simply 'take note' of the enquiry's report (Doig, 1984: 154-5).

If all this suggests that it is reasonable to take degrees of effective action as being indicative of levels of public concern (suggesting that the authorities have been forced to move beyond mere tokenism), then 1994 represents a sea change, for it was the year that saw the establishment of the Committee on Standards in Public Life (then known by the name of its chairperson, as the Nolan Committee). This came about as the result of a long series of episodes of 'sleaze', a term which, by bringing disparate issues into a single category, as mentioned, served thereby to focus media attention upon them (Doig, 1996: 50). An advisory, non-departmental body of the Government (ANDB) - that is, a body whose remit is to provide ministers with advice on a particular policy area - Nolan's terms of reference were to

examine current concerns about standards of conduct of all holders of public office, including arrangements relating to financial and commercial activities, and make recommendations as to any changes in present arrangements which might be required to ensure the highest standards of propriety in public life.

Nolan differed from the previous initiatives described above in terms of (a) its longevity (b) the nature of its recommendations and (c) the impact of its work:

(a) When the Committee was set up, the Prime Minister envisaged that it would remain in being as a standing body 'to advise the Government of the day' (Cabinet Office, 2001: 3) - though as an ANDB it is subject to quinquennial review to establish 'the continuing need for, and suitability of, the body for its 
purposes' (Cabinet Office, 2001: 2). The first review, in 2000, concluded that there was a 'continuing need to monitor the ethical environment' (Cabinet Office, 2001: 6) and in January 2007, the Committee published its eleventh report. Whereas the bodies described in the foregoing paragraphs tended to be wound up once they had fulfilled their terms of reference, the Committee on Standards has, in the words of the 2000 review report, 'become part of [the] fabric' 'it was put in place to review' (Cabinet Office, 2001: 6).

(b) While some of the Committee's recommendations have reflected - through its calls for codes of conduct and such like - a traditional emphasis on securing standards through discretion and self-regulation (on the assumption that values and standards generally remain sound), it has arguably been more willing than the previous bodies mentioned to look at the procedures and organisational arrangements needed to underpin these standards. This is not the place to go into a detailed list of its proposals, but significantly, as a result of its early recommendations, 'Parliament agreed in October 1995 to the creation of a new Committee on Standards and Privileges to replace the existing Committees on Members' Interests and on Privileges'. It also agreed to appoint a Parliamentary Commissioner for Standards, to place a ban on MPs lobbying on behalf of outside interests solely for payment, and to record MPs' outside earnings (within given bands) in the Register of Members' Interests (Doig, 2003). The Committee subsequently recommended that bribery in relation to MPs be criminalized ${ }^{2}$ and in recognition of the need for a more proactive control environment, it has taken an equally prescriptive approach in its reviews of other areas such as local government (Doig, 2003).

(c) Through its emphasis on the standards of conduct to be expected of public officeholders, the Committee's work has arguably contributed to the emergence of the new public management with its emphasis on quality of service delivery generally, and thus on performance indicators, external auditing and a perception of the citizen's relationship to the state as being first and foremost that of a consumer of government services. If this in turn has led to the development of growing expectations about responsiveness, ${ }^{3}$ and about citizens' individual rights in their interaction with public service-providers then, in accordance with Tocqueville's paradox, ${ }^{4}$ it has, not surprisingly, also contributed to a growing cynicism about

\footnotetext{
${ }^{2}$ In deference to the separation-of-powers principle, MPs had been beyond the reach of the main body of relevant legislation, the 1889, 1906 and 1916 Corruption Acts.

3 '...the proportion of consumers who expect any complaint they make in person to be dealt with either "immediately" or on the "same day" has increased from 56\% in 2001 to $65 \%$ in $2003 \ldots$ consumers in the same survey identified "Government" as the second worst industry for handling complaints effectively...' (DCA, 2004: 23).

${ }^{4}$ 'Tocqueville's paradox was based on his studies of the French Revolution which led him to observe

that in none of the decades immediately following the Revolution did our national prosperity make such rapid forward strides as in the two preceding it.... It is a singular fact that the steadily increasing prosperity, far from tranquilizing the population, everywhere promoted a spirit of unrest. Moreover, those parts of France in which the improvement in the standard of living was most pronounced were the chief centers of the Revolutionary movement..... It was precisely in those
} 
public life generally - a feeling that, in areas from education to the health service and party funding, values of integrity and service cannot be relied upon and, in the absence of external regulations and controls, will almost certainly be swept aside by the pursuit of private interests.

Survey data, media reports and government initiatives all, then, serve to make a strong case for the existence of a growing level of public anxiety about the integrity of public office holders since the early 1990s. What has caused it? The answer is necessarily speculative, but four factors seem important. First, we have already noted the growing attention of the mass media to issues of corruption and integrity, and it is not unreasonable to suggest that this, in turn, is related to the end of the Cold War (a suggestion that would help to make sense of the fact that the growth in public anxiety appears to be cross-national, not merely British). The end of the Cold War will have been important because of what it meant for the deep-seated ideological conflicts between left and right which the power struggle between the US and the USSR at the level of international politics had served to underpin. Everywhere, policy differences between mainstream parties of the left and right are much harder to identify than in the past and this means that the terrain of political conflict has to a degree shifted from that of policy to that of morality with parties increasingly attempting to compete with each other by throwing mud and attempting to damage each other by fomenting scandal, as the Lewinsky affair in America showed so forcefully - a phenomenon that Ginsberg and Shefter (2002) have called 'politics by other means'.

Second, this tendency has probably been reinforced by two interlinked sets of developments in politics and the media. First, there has been the shift from 'party-' to 'candidate-centred' campaigning - declining ideological conflict having shifted attention from position to valence issues and thus to candidates' competence; television and other electronic media, by allowing candidates to appeal directly to voters, having diminished the requirement for good party organisation and thus the attention to party itself in campaigns. Second, development of the mass media of communications has rendered the lives of the individuals who walk on the public stage 'much more visible than they ever were in the past' (Thompson, 2000: 6). Not only have they detached publicness from copresence and allowed distant others to be audible and visible at the moment they act, but most importantly, the electronic media have made possible a shift from rhetorical aloofness to mediated intimacy, through which politicians can present themselves not just as leaders, but as human beings - and the more politicians have sought to present themselves as 'one of us', the more their audiences have been inclined to assess them in terms of their character as individuals (Thompson, 2000: 39-41). True, television has been around for decades. But it is only since somewhere in the 1960s that exposure to it has effectively been universal and thus only since round about 1990 that the entire electorate has consisted of persons for whom televised politics has ever been a routine aspect of their experience.

Third, the past twenty years have arguably witnessed change of unprecedented

parts of France where there had been most improvement that popular discontent ran highest. [Pp. 174-76]' (Wolf Jnr., 1970: 790) 
rapidity in public values of all kinds, with concomitant changes in the kinds of behaviour the public regards as acceptable and unacceptable. The combined effect of these twin developments may have been to make it very difficult for politicians and other public officials to know exactly where the line between right and wrong is drawn - the result being a growing number of corruption scandals of various kinds. Significantly influenced by globalisation, normative uncertainty will also have fed anxiety about the integrity of public office holders by raising doubts about the extent to which publicly pronounced values reflect what office holders actually do: No more 'a self-contained source of sovereign political power and normative autonomy', the national state continues to claim to defend public against private interests within its borders, even while including, protecting and bowing to powerful private interests beyond its borders (Tsoukalas, 2006: 40).

Finally, the growth in media attention to issues of corruption and integrity, and thus the growing public anxiety, may reflect an objective increase in the incidence of misconduct itself. There are at least two (related) reasons for thinking that this may have happened. One has to do with the legacy of the Thatcher years. These have bequeathed a political culture in which 'the encouragement of financial gain as an indicator of worth, has placed a premium on self-centred secularism and materialism' (Doig, 2003), as well as bequeathing an unbending belief in government circles that 'private sector values, procedures and practices [provide] the best framework for the delivery of public services either by the private or public sectors' (Doig and Wilson, 1995: 17). Several official reports in the 1990s expressed concerns about the possible impact of such a background on standards in public life. Meanwhile, it is possible that the same political culture 'of fragmented "free rider" attitudes in everyday life' has contributed to the well-known decline in party membership of recent years, bringing increased financial pressure on parties less able to rely on 'free contributions of funds and energy' and forced increasingly to rely on the services of paid professionals (Tsoukalas, 2006: 46). ${ }^{5}$ Support for the thesis of cash-strapped parties bowing to illegitimate influence appears to be offered by the growing salience, among instances of presumed misconduct, of allegations relating to party funding - an issue that has itself acquired growing salience since the PM's 1997 decision to extend to it the terms of reference of the Standards Committee.

\section{Public perceptions}

As Mortimore (1995: 31) notes, evidence about public perceptions of the conduct of politicians is sparser before than after about 1985 and this in itself is telling of a change in the climate of opinion: 'If no polls were carried out to determine whether the public thought MPs were corrupt, one reason may well have been that few people were suggesting that they were'. The question that exercises us here is how the changed climate has been articulated in terms of the public's views about: what is acceptable on the part of public office holders, how far their behaviour in fact conforms to it and how

\footnotetext{
${ }^{5}$ The Electoral Commission (2004: 9) cites data suggesting that Labour Party membership declined from 405,238 in 1997 to 214,952 in 2003, membership of the Liberal Democrats from 100,000 to 73,305, and Conservative Party membership from 400,000 to 320,000.
} 
likely they are to be held responsible if it does not so conform. Our data come from the national surveys of public attitudes towards the standards of conduct of public office holders that were carried out, in 2003-2004 and in 2005-2006, for the Committee on Standards.

The British are, it would seem, rather strict in terms of the standards of behaviour they expect of their public officials. Not surprisingly, overwhelming majorities (2005-06 survey) think it 'very' or 'extremely' important that MPs and government ministers should not use their power for their own personal gain (93.3 percent) and should not take bribes (96.9 percent). However, it is also the case that large majorities think it unreasonable, in voting in Parliament, for MPs to 'take into account' what would benefit their families (84.1 percent); how their decisions might affect their chances of getting a job outside politics (83.8 percent); how the decision might affect their political careers (74.9 percent), and even what will make their party more popular with the general public (61.2 percent). While the first two of these results are understandable in that they relate to conduct that could be more or less clearly construed as 'corrupt' in some sense, the last two speak eloquently to the rather rigid nature of attitudes towards integrity: from a more relaxed perspective, it might be thought unrealistic to expect an MP never to 'take into account' the likely personal consequences of a decision and indeed that consequences such as the last two are part of the 'normal' mechanisms for ensuring that public decisions remain in tune with majority wishes in a democracy. For some (11.9 and 16.3 percent respectively), the demand for moral rectitude even extends to the beliefs that it would be unacceptable for a council official to encourage a friend to apply for a council job for which s/he thinks the friend would be suited, or tell the friend where they can find publicly available information about the job (2003-04 survey). Moreover, the British appear to demand a higher standard of conduct of those who walk the public stage than they would be prepared to tolerate in others: 59.9 percent of respondents to the 2005-06 survey thought it was 'very', or 'extremely' important that MPs and government ministers 'set a good example for others in their private lives', 54.6 percent that senior public officials did so.

Unfortunately, people do not, by and large, see those in public life as actually living up to the expectations they have of them: 91.8 percent believe that at least 'a few' MPs use their power for their own personal gain, 48.7 percent that 'about half' or more do so. And if only 8 per cent believe that 'all' or 'most' MPs take bribes, then 71.8 per cent believe that at least 'a few' do so (2005-06 survey). Not surprisingly, then, only a minority - 28.3 percent - would 'generally trust' MPs to 'tell the truth', although significantly, the proportion climbs to 45.8 percent when the question is asked about 'your local MP'. This element of actual or potential 'closeness' to the affairs of the respondent personally appears to have a big impact on perceptions. Thus, while large majorities would generally trust family doctors, head teachers, judges and senior police officers to tell the truth, only minorities - between about a fifth and a third in each case would likewise trust senior council managers, government ministers, and top civil servants.

If mistrust of the 'remoter' public officials is, then, rather widespread, the 
expectation must be that few will have much confidence in the mechanisms for holding such officials responsible for their conduct. The data appears to bear out this expectation. Thus while a majority of 55.1 percent (2005-06 survey) are 'very' or 'fairly' confident that the authorities are committed to improving standards, nevertheless, most are 'not very' or 'not at all' confident that the authorities will uncover wrongdoing by people in public life (54.3 percent) or that, once having uncovered the wrongdoing, the authorities will punish the persons concerned (58.2 percent). If people feel the wrongdoing by public office holders will be uncovered, then it is the media they feel will do the uncovering, not the authorities: twice as many (80.7 percent) are 'fairly' or 'very' confident that the media will uncover wrongdoing as are 'fairly' or 'very' confident that the authorities will do so (42.2 percent).

How are we to interpret these data? In the first place, the general mistrust and lack of confidence they portray appears to be rather stable. Writing a decade ago, Mortimore (1995: 31, 32, 40) noted, as we have done, the findings of surveys suggesting that the public took 'a strict view' of what was acceptable in public life; that the public were also 'quite convinced that British politicians' were 'not living up to those expectations', and that '[d]istrust of politicians naturally enough [lead] to distrust of political institutions'. With all due allowance for variations in the response categories, it is striking how similar the ordering of groups the public would 'generally trust to tell the truth' is in 2003 to the ordering the same question produced in 1983 and 1993: Table 1. Over the twenty-year period, while most groups show an improvement in the extent to which they are trusted, their relative positions stay virtually the same. In the second place, therefore, we seem to be in the presence of generalised impressions about public officials (that may get 'better' or 'worse' with time) rather than anything that could be appropriately described as specific beliefs influenced by knowledge. And since this is the case, it is not surprising that for many, the specific beliefs they do hold are quite contradictory. For example, approaching a third of the public in 2003 trusted neither elected nor appointed officials at either the local (councillors, senior council managers) or national levels (MPs, ministers, top civil servants). Yet of these, 26.3 percent nevertheless rated 'the standards of conduct of public office holders in Britain' overall as 'quite' or 'very' high, only 20.1 percent rating them as 'quite' or 'very' low. Again, 28 percent said they trusted MPs generally to tell the truth, but then 39 per cent of these went on to suggest that half or more used their power for their own personal gain, 13 percent suggesting that half or more actually took bribes! Fourth, therefore, we see these findings as reflecting what we can only describe as rather immature attitudes towards public office holders and political representatives, people relating to them almost as if they were parental figures. Thus, on the one hand people expect senior office holders to act as role models for them, exemplifying much higher standards than those they would tolerate in others - but then they show a level of cynicism about how the office holders actually behave that appears to be mainly a function of lack of familiarity with their work: as soon they are asked to reflect on groups 'closer to home', exaggeratedly negative perceptions disappear.

What, then, are the characteristics of respondents that are most likely to give rise to this syndrome? Socio-demographic variables such as age, education and socioeconomic status appear not to be significantly related to it, suggesting that we are dealing 
with a general, cultural phenomenon that cuts across standard sociological categories. Taking trust in MPs to tell the truth as our indicator, the figures in Table 2 suggest that the only significant predictor of lack of trust is being aged between 55 and 64, all the other factors being non significant $(p>0.05)$. Behavioural and attitudinal characteristics, such as interest in current affairs, a sense of political efficacy and trust in others generally, tell a different story. While interest in current affairs makes little difference, the extent to which respondents feel they can influence political decisions, and whether or not they are able to exhibit interpersonal trust, do have an effect. In order to assess the impact of each of the significant factors net of the impact of each of the others, we entered them into a logistic regression model with trust in MPs as the dependent variable where 'do not trust' $=1$; 'trust' $=0$. The result was that the variables 'age 54-65' and 'can influence decisions: agree' were non-significant. This being the case, the model was rerun without them, with the results shown in Table 3. These suggest that, as compared to those who strongly agree, those who disagree that they 'can influence decisions affecting this country' are between one-and-a-half and two-and-a-half times as likely to believe that MPs cannot be trusted to tell the truth. Meanwhile, those who strongly disagree that they 'can influence decisions affecting this country' are between 1.6 and 3.8 times as likely as those who strongly agree to believe that MPs cannot be trusted to tell the truth - while those who believe that generally speaking 'you can't be too careful dealing with people' are between one-and-ahalf and two-and-a-half times as likely to hold this belief as those who feel that generally speaking 'most people can be trusted'.

Negative perceptions of the integrity of public office holders appear, in short, to be closely tied to a general disdain and distrust of elected and appointed representatives. Rooted in a relative lack of social capital and a sense of being unable to count politically, such perceptions are consequently rather stable and widely shared across the population. This being the case, it is as likely that the perceptions are a cause of specific allegations of misconduct (by providing fertile ground for media speculation and investigation) as it is that they stem from specific allegations - thus giving rise to the real danger of the development of vicious circles and downward spirals. This then recalls the point made earlier - that the state's attention to how its representatives' conduct is perceived must be constant if their authority is not to be dangerously compromised - thus throwing a spotlight on the final issue to be considered: the role of the recent policy responses in concerns about integrity.

\section{The role of the policy response}

This role is best examined by looking at: the way in which policy has been formulated; the substance of the policy enacted and implemented; the effectiveness and impact of the policy.

As far as the first of these is concerned, it is noteworthy that the period since the establishment of the Standards Committee has seen the creation of a range of institutions whose remits include activities contributing to the formulation of policy (understood as decisions relating to the drafting of legislation and other rules) in the area of integrity. 
They include:

- the Office of the Parliamentary Commissioner for Standards, set up in 1995, the remit of which includes monitoring the operation of the Code of Conduct and Rules relating to the conduct of MPs and where appropriate, proposing modifications to the Commons' Select Committee on Standards and Privileges (which oversees the work of the Office).

- the Propriety and Ethics Team within the Cabinet Office. Its responsibilities include 'maintaining an effective working relationship between government and the Committee on Standards in Public Life, including advising the Prime Minister on its work'. It is also responsible for 'providing advice to departments about issues arising under the Ministerial Code, Civil Service Code and Code of Conduct for Special Advisors' (Cabinet Office, 2005: 44).

- The Office of the Commissioner for Public Appointments, set up in November 1995, with the remit of establishing a code of conduct for ministerial appointments to public bodies, thus enabling it to ensure that such appointments are made on the basis of merit after fair and open competition.

- The Electoral Commission. Set up by the Political Parties, Elections and Referendums Act 2000, its remit includes keeping under review and advising the Home Secretary on the law relating to party funding, political advertising and other matters associated with the conduct of elections.

- The Standards Board for England. Set up in March 2001 its remit is to ensure that members of local authorities adhere to ethical standards (including those relating to abuse of office, misuse of resources, and conflicts of interest) and to investigate allegations 'that members' conduct may have fallen short of the required standards' (www.standardsboard.co.uk).

In addition to the above, each of the so-called 'devolved institutions' (that is, the National Assembly for Wales, the Northern Ireland Assembly, the Scottish Parliament and the Greater London Assembly) have standards commissioners and standards committees with functions very similar to those of the House of Commons' Parliamentary Commissioner and its Select Committee on Standards and Privileges.

The role, in policy formulation, of the consultation activities of these bodies illustrates rather well the point about the significance of constant attention to public perceptions in ensuring that the authority of public office-holders remains intact. The Committee on Standards itself conducts most of its work through a continuous series of consultations involving: the publication of 'questions and issues' documents to which it invites written responses; public hearings, and meetings with specialists and experts. Each consultation round then culminates in the publication of a report and recommendations (which are then presented to Parliament as a 'Command Paper' ${ }^{6}$ ). In addition, it has responded to its remit 'to examine current concerns' about standards by commissioning research into what the public sees as the key issues in this area (the two surveys analysed in the preceding section). Having decided to repeat the surveys on a biannual basis to track changes in perceptions and attitudes over time, the Committee has

\footnotetext{
${ }^{6}$ That is, a paper 'laid before Parliament as conveying information or decisions which the Government think should be drawn to the attention of one or both Houses of Parliament' (House of Commons, 2003: 2).
} 
concluded from the first two surveys 'that the public place a high priority on a much broader definition of honesty than is currently described by the Committee' (Graham, 2004) ${ }^{7}$ and that related to this, the key public concern in relation to standards currently has less to do with financial probity than it has to do with spin. Likewise, the Electoral Commission has also drawn on investigations of public attitudes in formulating its recommendations. Most notably, it commissioned a survey, carried out in May 2003, to measure public knowledge of the system of party funding and their attitudes towards the way the system might develop in the future, together with a follow-up series of focus groups in November 2003. The research found that levels of awareness of funding arrangements were low and that attitudes were confused and contradictory. Thus while a large majority thought that people should have the right to donate to parties, a large majority also thought that this was unfair as it risked the buying of influence. Likewise, while concerned that the risk of influence-buying by the wealthy was a real one, a very large majority (76 percent) was opposed to the state funding of parties (Electoral Commission, 2004: 15). The upshot was that in the face of public hostility to such a reform, and in awareness of the significance of large donations in helping parties overcome the difficulties of covering their costs, the Commission in its December 2004 report recommended that the absence of limits on the size of permissible donations be allowed to continue (Electoral Commission, 2004).

One's impression, then, is that the period since the setting up of the Standards Committee has seen a wide range of proposals being formulated in accordance with democratic principles of consultation and sensitivity to public concerns. A rather similar impression emerges from a survey of the reforms actually enacted and implemented. The principal changes, in addition to those described in the preceding paragraphs of this section have been:

- The July 1995 House of Commons Resolution endorsing a code of conduct for Members (which now sets out detailed rules on registering interests and avoiding conflicts of interest) and its November 1995 Resolution imposing a ban on paid advocacy in Parliament.

- Legislation, in the Public Interest Disclosure Act 1998, offering legal protection to workers who 'blow the whistle' on wrongdoing.

- The Local Government Act 2000. This, besides setting up the above-mentioned Standards Board for England, obliged local authorities to adopt codes of conduct setting out rules governing the behaviour of their members and incorporating the provisions of a model code of conduct which was approved by Parliament in November 2001. The Act also obliged the authorities to set up standards committees (with responsibility for overseeing observance of the codes of conduct) and required members to declare financial interests in registers of members' interests. Finally, the Act obliged members to disclose interests before taking part

\footnotetext{
${ }^{7}$ The reference here is to the famous 'seven principles of [conduct in] public life' (selflessness, integrity, objectivity, accountability, openness, honesty, leadership) set out in the Committee's First Report and which have since provided the framework for the adoption of Codes of Conduct throughout the public sector. In setting out the principles, the Committee defined 'honesty' as meaning that 'holders of public office have a duty to declare any private interests relating to their public duties and to take steps to resolve any conflicts arising in a way that protects the public interest'.
} 
in any business of the authority relating to that interest, obliging authorities to prevent or restrict the participation of members with interests, in business relating to those interests.

- In an attempt to introduce greater transparency into party-funding arrangements, and to encourage public confidence that influence was not being bought with parties, Parliament passed the Political Parties, Elections and Referendums Act 2000. In setting up the Electoral Commission, the Act obliged parties to submit periodic statements of their accounts to the Commission and placed a ban on foreign or anonymous donations to parties. Non-financial forms of support were to count as donations and the Act introduced, for the first time, overall spending limits (as opposed to limits, which already existed, on spending by single candidates) by parties in election campaigns.

- Following recommendations contained in the Standards Committee's First Report, ministers have been placed under an obligation to give notice, to the Advisory Committee on Business Appointments (ACBA), of any intentions to take up within two years of leaving office, any alternative employment. ${ }^{8}$ However, unlike civil servants, ministers are not obliged to accept ACBA's advice.

- The Freedom of Information Act 2000. From January 2005, the Act created a general right of access, subject to some absolute and some qualified exemptions, to information held by public bodies. Applicants who feel that their requests for information have been wrongly turned down, may appeal to the Information Commissioner, an independent official who reports annually to Parliament and whose Office oversees operation of the Act.

- The 2001 Anti-terrorism, Crime and Security Act - incorporating the OECD's 1999 Convention on the bribery of overseas officials. This obliges signatory states to make it illegal for companies based within their borders to attempt to bribe foreign public officials in the course of international business transactions.

What are we to make of the impact on perceptions of all this policy-making activity? This is obviously a difficult issue, but three points can be made. In the first place, despite the volume of legislation it has produced, it does not appear to have reduced the general salience of the integrity of public office-holders as a political issue. Indeed, to judge impressionistically from the number of allegations of misconduct that appear daily to hit the headlines, it may even have helped to raise it: for its result has been to create an 'institutional ethics framework' all of whose bodies - the Committee on Standards, the Parliamentary Commissioner, the Standards Board, the Electoral Commission and so forth - now publish annual reports 'which ultimately inform the public on the ethical state of the country' (Doig, 2004: 446). Moreover, the paradoxical effect of a growing volume of legislation concerning standards is arguably to increase the likelihood of misconduct through a multiplication of the rules there to be broken - and thereby the likelihood of public outcry given the 'increasing disengagement of the media in reporting on politics as an activity rather than focussing on scandals and personalities' (Doig, 2004: 448). This, as the recent activities and reports of the Standards Committee suggest, then

\footnotetext{
${ }^{8}$ ACBA 'was set up in 1975 to scrutinise the movement of senior civil servants into business positions where their inside knowledge of government might be of commercial value' (http:// www.againstcorruption.org/BriefingsItem.asp?id=12964).
} 
gives rise to demands that perceived gaps in the integrity system be plugged - resulting in further reform, and a further twist to the circle. ${ }^{9}$ Finally, the growing profile and complexity of the ethical framework increases the opportunities for the launching of vexatious complaints and a 'hightened political tit-for-tat antagonism' (Doig, 2004: 444) in conduct cases - which must necessarily contribute further to keeping the profile of the issue high. $^{10}$

Second, much of the legislative activity described above has ultimately been driven by recommendations originating with the Committee on Standards, which has interpreted its remit rather broadly. The Seven Principles of Public Life (note 7) which have had such a high profile in all the Committee's public communications (they are published at the beginning of all its official documents, for instance) themselves include tenets - such as 'openness' and 'leadership' - whose relevance includes but goes well beyond conduct construable as 'corruption' narrowly understood. And in fact, if corruption has to do with (ab)using a public position dishonestly to gain a 'personal' or 'private' advantage, then it is objectively very difficult to know precisely what material difference there is between straightforward bribery of the kind alleged in the 'cash-forpeerages' affair, ${ }^{11}$ favouritism of the kind alleged in the appointment of Trevor Phillips as Chair of the Commission for Racial Equality ${ }^{12}$ or deception in the handling of information of the kind alleged in the way in which the events leading to the Iraq war were handled. All involve a sacrifice of openness and integrity to the demands of practical politics and therefore constitute an objective threat to public confidence by confirming empirically for citizens that they are correct not trust public officials. It is not surprising, then, that the Standards Committee has tended to cast its net very widely. Its recommendations have touched on issues that border on questions of financial probity but actually spill over into other areas (for example, discrimination, and freedom of information, as they relate, for example, to impartiality in appointments procedures); and the Committee has constantly sought to maximise the area and depth of application of its strictures, insisting repeatedly that all public bodies should draw up codes of conduct incorporating the seven principles, that these codes should be supported by independent

\footnotetext{
${ }^{9}$ For example, having persuaded Parliament, in the 1990s, to reform itself through acceptance of its recommendations for a code of conduct, a Commissioner and more detailed rules on the declaration of interests, the Committee on Standards has, on more than one occasion since, reviewed the reforms, each time proposing amendment. See, for example, its sixth report and its eighth report available through its web site, http://www.public-standards.gov.uk/

${ }^{10}$ It was said, for example, that because of her zealousness, and the way she handled investigations, the second Parliamentary Commissioner for Standards, Mrs Elizabeth Filkin, created a climate in which there was an increase in cases driven by ulterior, political, motives (Doig, 2004: 444).

${ }^{11}$ This is the term used by the media to refer to the scandal that broke in early 2006, when the House of Lords Appointments Commission rejected a number of the nominations for peerages put forward by the Prime Minister. It later emerged that they had loaned large sums of money to the Labour Party, where these loans had been kept secret since the 2000 Political Parties, Elections and Referendums Act did not require loans, even those given for an indefinite period, to be made a matter of public record, unlike donations.

${ }^{12}$ Allegations of bias arose from the fact that Phillips was a former Labour candidate and a friend of many senior Labour figures, this raising doubts about the extent to which, in making the appointment, the Home Secretary had sacrificed impartiality to the Government's political agenda in the area of race.
} 
scrutiny, and that they should be constantly embedded into institutional cultures through guidance and training including induction training. Given the sheer breadth of such an approach to standards in public life, it is hardly surprising, then, if the issue itself continues to remain high on the political agenda.

Finally, in any assessment of the impact of the policy-making activity on perceptions, one needs to ask about how effective the measures have been in actually improving the position regarding (revelations of) corruption and dishonesty. 'We cannot' - to borrow the words of the Standards Committee's First Report - say conclusively that standards of behaviour in public life have declined'. We can say that public allegations about that behaviour appear to have declined little in either frequency or gravity. If anything the opposite seems the case. ${ }^{13}$ This is perhaps not surprising as it seems difficult on the face of it to devise rules that do not conflict in some way with other socially desirable ends or that can offer anything like a guarantee of immunity from accusations of misconduct. For example, in its First Report, the Standards Committee recognised that much of the lack of confidence in the financial probity of MPs had to do with 'the very substantial increase in the number of Members of Parliament employed as consultants and advisors to companies, trade associations and the like' - but set its face against restraints on MPs' freedom to have outside jobs on the not unreasonable grounds that a House of Commons without members with a continuing wide variety of outside interests 'would be less well-informed and effective... and might well be more dependent on lobbyists' (Committee on Standards in Public Life, 1995: 21, 23). And while the Commons' 'Guide to the Rules relating to the conduct of Members' is absolutely clear about the obligation on MPs to disclose in any debate or proceedings 'any relevant pecuniary interest or benefit of whatever nature, whether direct or indirect, that he may have had, may have or may be expecting to have' - the Guide is also frank in its acknowledgement that 'It is the responsibility of the Member, having regard to the rules of the House, to judge whether a pecuniary interest is sufficiently relevant to a particular debate, proceeding, meeting or other activity to require a declaration' (House of Commons, 2005: 21, 22). Here, then, we have a likely third set of reasons for the apparently continuing presence on the public's agenda of integrity as a political issue.

\section{Conclusion}

From the starting point that the full significance for contemporary democracies of political corruption cannot be grasped without an understanding of citizens' moral codes and perceptions of official misconduct, we have sought to: account for the growing levels of public concern in Britain since the early 1990s; consider how citizens articulate this concern; explore how official responses and the way they have been formulated may have contributed to citizens' concerns. We believe that the fundamental causes of growing concern are to be found in the way in which a number of political and social changes have impacted on the kinds of issues to which the mass media devote attention

\footnotetext{
${ }^{13}$ At the time of writing, the 'cash-for-peerages' affair has been joined by revelations of the decision of the Serious Fraud Office to drop investigations, apparently under pressure from Downing Street, into allegations of bribery of Saudi officials by arms manufacturer BaE.
} 
and therefore on the kinds of agendas they set for mass publics. We think that citizens' concerns have given rise to a generalised cynicism about public office-holders whose deep-rooted quality can be seen in the fact the outlines of such cynicism appear to be pretty much the same now, after - and notwithstanding - considerable legislative activity stemming from the work of the Standards Committee, as they were before the Committee was established. Paradoxically, the very efforts to address public anxieties have helped to keep such anxieties alive, acting as a self-negating prophecy. Political corruption and similar forms of misconduct are an extreme form of the sacrifice of principles to the demands of practical politics. We suspect that public perceptions and attitudes are unlikely to change until such time as a way can be found to supplant the non-ideological, practical politics of early twenty-first century Britain with the more principled disagreements that animated politics before the rise of Margaret Thatcher and her New Labour imitators.

\section{References}

Cabinet Office (2001), 'Report of the quinquennial review of the Committee on Standards in Public Life', www.cabinetoffice.gov.uk/propriety_and_ethics/publications /pdf/quinreport.pdf

Cabinet Offcie (2005), 'Departmental Report 2005', Cm 6543, http://www.officialdocuments.gov.uk/document/cm65/6543/6543.pdf

Committee on Intermediaries (1950), Report of the Committee on Intermediaries, Cm. 7904, www.bopcris.ac.uk/bopall/ref8931.html

Committee on Standards in Public Life (1995), 'First Report of the Committee om Standards in Public Life', Volume 1: Report, Cm 2850-1, http://www.archive.officialdocuments.co.uk/document/cm28/2850/285001.htm

Day, Peter (2000), 'Attlee’s Government was Riddled with Sleaze', The Independent, 5 January, p.8.

DCA [Department for Constitutional Affairs] (2004), 'Delivering Justice, Rights and Democracy: DCA Strategy 2004-09', www.dca.gov.uk/dept/strategy/dcastratfull.pdf

Doig, Alan (1984), Corruption and Misconduct in Contemporary British Politics, Harmondsworth: Penguin.

Doig, Alan (1996), 'From Lynskey to Nolan: The Corruption of British Politics and Public Service?’, Journal of Law and Society, vol. 23, no. 1, March 1996, pp.36-56.

Doig, Alan (2003), 'Political Corruption in the United Kingdom', in Martin J. Bull and James L. Newell (eds), Corruption in Contemporary Politics, London: Palgrave. 
Doig, Alan (2004), 'Ethics, Sleaze and Codes: the Politics of Trust', Parliamentary Affairs, vol. 57, no. 2, pp.435-452.

Doig, Alan and Wilson, John (1995), 'Untangling the Threads', pp.14-30 in F. F. Ridley and Alan Doig (eds), Sleaze: Politicians, Private Interests and Public Reaction, Oxford: Oxford University Press.

Electoral Commission (2004), 'The funding of political parties: Report and recommendations', http://www.electoralcommission.org.uk/files/dms/partyfundingFINA Lproofs_15301-11394_E_N_S_W_.pdf

Ginsberg, B. and M. Shefter (2002), Politcs by Other Means: Politicians, Presecutors, and the Press from Watergate to Whitewater, $3^{\text {rd }}$ edition, New York and London: W. W. Norton.

Graham, Sir Alistair (2004), Oral communication to the press conference given by the Committee on Standards in Public Life, 8 September [transcript of Conference by Eleen Fox for Radio Technical Services, http://www.public-standards.gov.uk/upload/assets /www.public_standards.gov.uk/survey_attitudes_press_launch.doc]

Harrison, Michael J. (nd), 'Understanding the Corruption Perceptions Index: Application Issues for the Foreign Direct Investment Decision', http://www.snhu.edu /UnderstandingCPI.doc

House of Commons (2003), 'Comand Papers', Factsheet P13 Procedure Series, http://www.parliament.uk/documents/upload/p13.pdf

House of Commons (2005), 'The Code of Conduct together with The Guide to the Rules relating to the conduct of Members', HC 351, http://www.publications.parliament.uk/pa /cm/code.pdf

Moncrieff, Chris (2005), 'A journalist looks at political scandal', in John A. Garrard and James L. Newell (eds), Scandal in Past and Contemporary Politics, Manchester: Manchester University Press.

Mortimore, Roger (1995), 'Politics and Public Perceptions', pp.31-41 in F. F. Ridley and Alan Doig (eds), Sleaze: Politicians, Private Interests and Public Reaction, Oxford: Oxford University Press.

Paterson, Peter (2000), ‘Clocking up another hit’, Daily Mail, 24 January, p.47.

Thompson, John B. (2000), Political Scandal: Power and Visibility in the Media Age, Cambridge: Polity Press. 
Transparency International, (1995), 'New Zealand Best, Indonesia Worst in World Poll of International Corruption', press release, http://www.transparency.org/content /download/2915/18031/file/cpi1995.pdf

Tsoukalas, Constantine (2006), 'On Political Corruption', paper presented to the Special Symposium on Political Corruption of the European Studies Research Institute, University of Salford, 6 December.

Wolf Jnr, C. (1970), 'The Present Value of the Past', The Journal of Political Economy, vol. 78, no. 4, pp. 783-792. 
Figure 1 CPI scores for the UK, 1995-2006

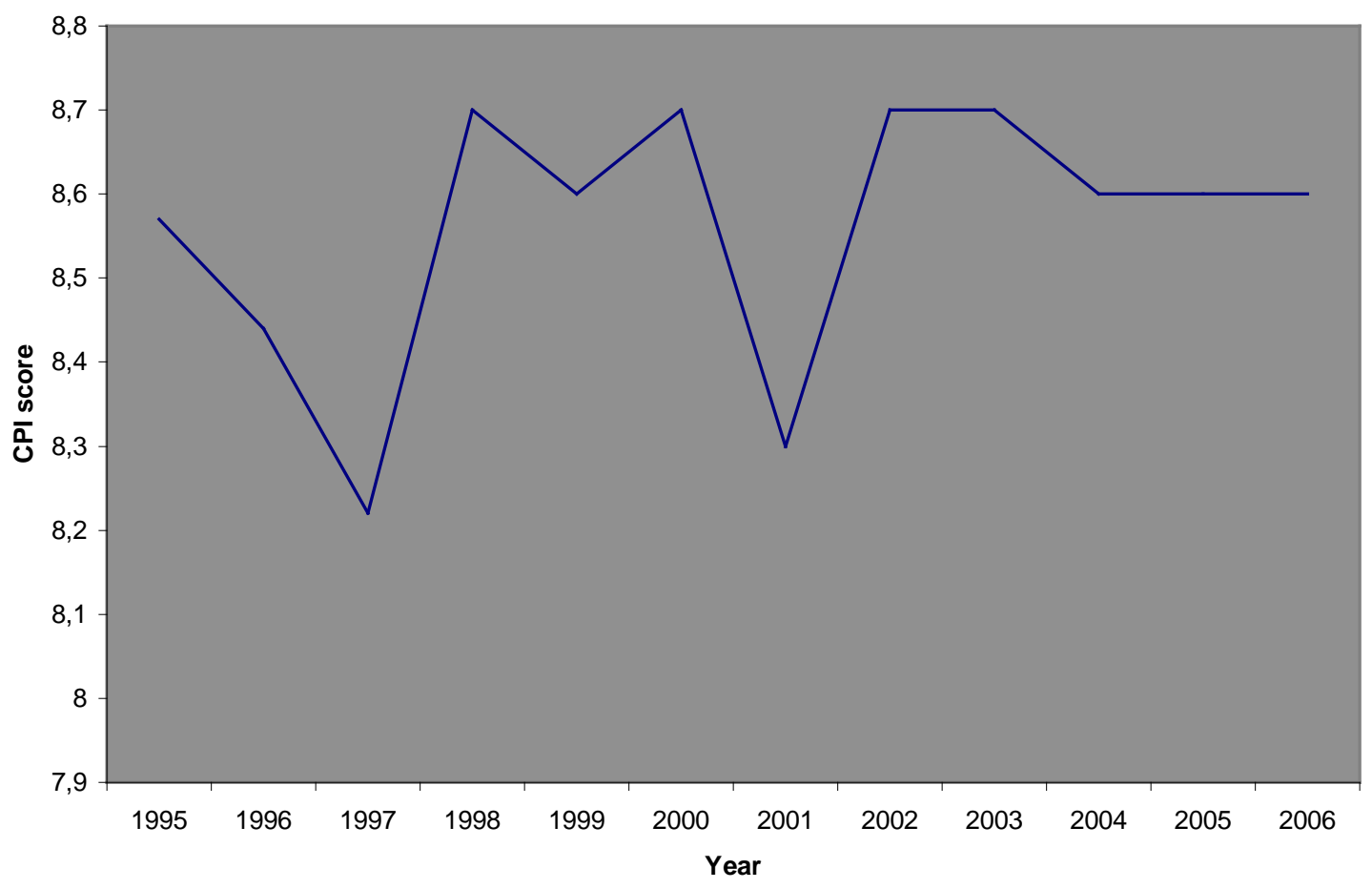


Figure 2 Guardian headlines containing the roots 'crroupt' or 'bribe' or 'embezzle' or 'fraud' or 'sleaze' 1984-2005

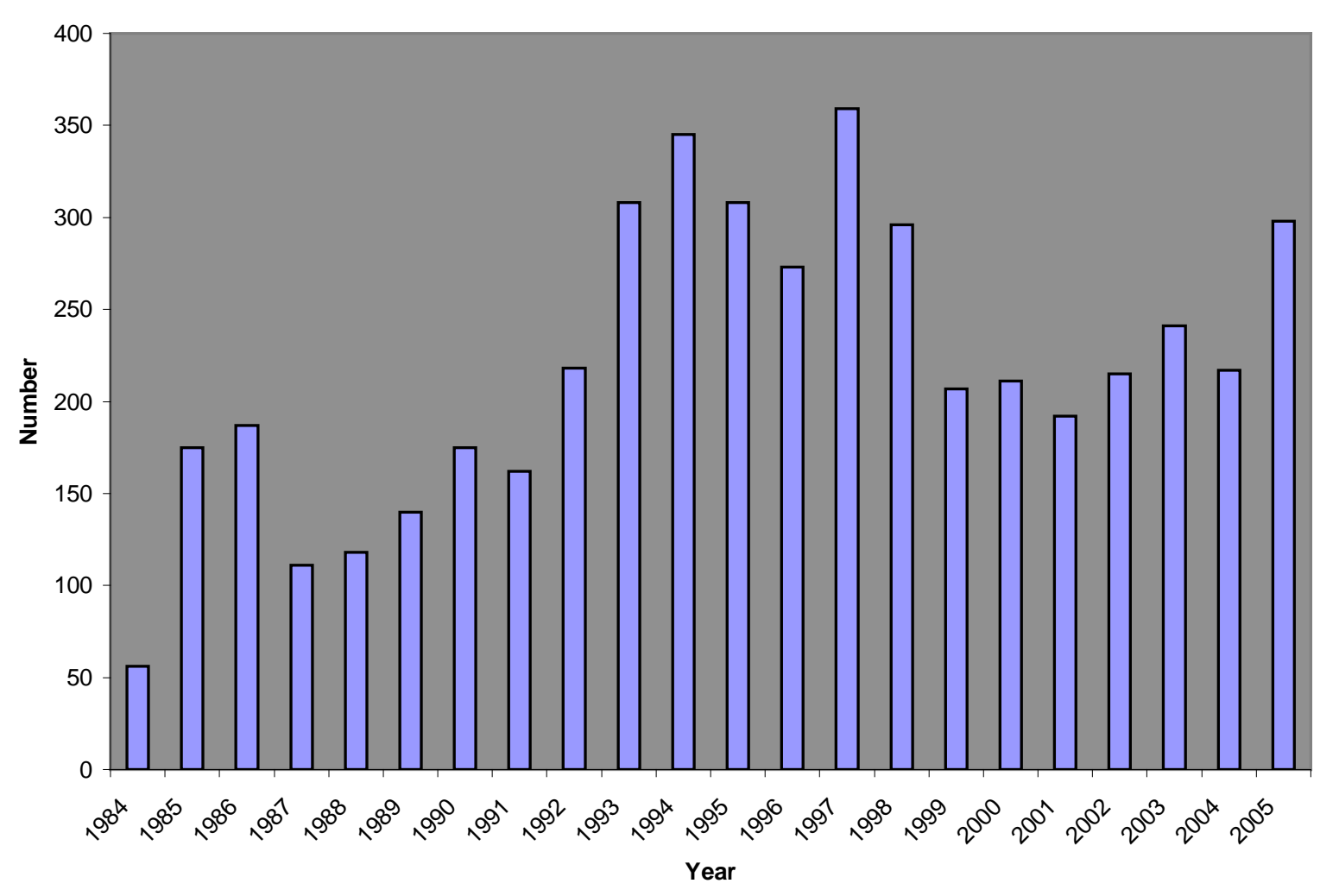


Table 1 Groups trusted or not trusted to tell the truth, 1983, 1993, 2003

\begin{tabular}{|c|c|c|c|c|c|c|c|c|}
\hline & \multicolumn{4}{|c|}{ Tell truth } & \multicolumn{3}{|c|}{ Not tell truth } & \multirow{2}{*}{$\begin{array}{l}\text { Net } \\
\text { improvement } \\
1983-2003 \\
1983-2003\end{array}$} \\
\hline & 1983 & 1993 & & 2003 & 1983 & 1993 & 2003 & \\
\hline & $\%$ & $\%$ & & $\%$ & $\%$ & $\%$ & $\%$ & $+\%$ \\
\hline Doctors & 82 & 84 & Family doctors & 92 & 14 & 11 & 8 & +16 \\
\hline Teachers & 79 & 84 & $\begin{array}{l}\text { Head teachers in } \\
\text { schools }\end{array}$ & 83 & 14 & 9 & 13 & +5 \\
\hline Judges & 77 & 68 & Judges & 79 & 18 & 21 & 16 & +4 \\
\hline \multirow[t]{2}{*}{ The Police } & \multirow[t]{2}{*}{61} & \multirow[t]{2}{*}{63} & $\begin{array}{l}\text { Local police officers on } \\
\text { the beat in your area }\end{array}$ & 77 & 32 & 26 & 17 & $+21 *$ \\
\hline & & & Senior police officers & 67 & & & 27 & \\
\hline $\begin{array}{l}\text { Television } \\
\text { news readers }\end{array}$ & 63 & 72 & $\begin{array}{l}\text { Television news } \\
\text { journalists }\end{array}$ & 49 & 25 & 18 & 46 & -35 \\
\hline Civil servants & 25 & 37 & Top civil servants & 37 & 63 & 50 & 54 & +21 \\
\hline $\begin{array}{l}\text { Politicians } \\
\text { generally }\end{array}$ & 18 & 14 & MPs in general & 28 & 75 & 79 & 66 & +19 \\
\hline $\begin{array}{l}\text { Government } \\
\text { ministers }\end{array}$ & 16 & 11 & Government ministers & 24 & 74 & 81 & 69 & +13 \\
\hline $\begin{array}{l}\text { Business } \\
\text { leaders }\end{array}$ & 25 & 32 & $\begin{array}{l}\text { People who run large } \\
\text { companies }\end{array}$ & 23 & 65 & 57 & 68 & -5 \\
\hline Journalists & 19 & 10 & $\begin{array}{l}\text { Journalists on } \\
\text { newspapers like the Sun } \\
\text { the Mirror or the Daily } \\
\text { Star }\end{array}$ & 7 & 73 & 84 & 89 & -28 \\
\hline
\end{tabular}

Sources: Mortimore, 1995, table 2; Survey of public attitudes towards conduct in public life 2003-04, BMRB Research.

Notes:

In 1983 and 1993, the question was: 'Now I will read out a list of different types of people. For each would you tell me whether you generally trust them to tell the truth or not?' In 2003, the question was: 'These cards show different types of people. Please put them on this board to show which you would generally trust to tell the truth and which you wouldn't'

* Net improvement calculated by using, for 2003, the mean scores for 'local police officers on the beat in your area' and 'senior police officers' 
Table 2 Predictors of trust in MPs generally to tell the truth (logistic regressions)

\begin{tabular}{|l|l|l|}
\hline Variable & Significance & Exp(B) \\
\hline Age 65+ & 0.333 & 0.857 \\
\hline Age 55-64 & $0.042^{*}$ & 1.534 \\
\hline Age 45-54 & 0.872 & 0.972 \\
\hline Age 35-44 & 0.644 & 0.925 \\
\hline Age 25-34 & 0.877 & 1.029 \\
\hline Degree & 0.795 & 1.054 \\
\hline Higher ed. diploma & 0.871 & 1.037 \\
\hline A levels & 0.679 & 0.908 \\
\hline Trade apprenticeship & 0.243 & 1.370 \\
\hline GCSE Advanced level & 0.057 & 1.584 \\
\hline GCSE Ordinary level & 0.591 & 0.889 \\
\hline Intermediate occupation & 0.365 & 1.175 \\
\hline Routine/manual occupation & 0.982 & 0.009 \\
\hline Never worked & 0.124 & 0.566 \\
\hline Full-time student & 0.346 & 1.505 \\
\hline Interest current affairs: quite a lot & 0.185 & 0.827 \\
\hline Interest current affairs: some & 0.551 & 1.092 \\
\hline Interest current affairs: not very much & 0.467 & 1.138 \\
\hline Interest current affairs: none & 0.650 & 0.860 \\
\hline Can influence decisions: agree & $0.000^{*}$ & 0.476 \\
\hline Can influence decisions: neither agree nor disagree & 0.066 & 0.723 \\
\hline Can influence decisions: disagree & $0.013^{*}$ & 1.425 \\
\hline Can influence decisions: strongly disagree & $0.000^{*}$ & 2.057 \\
\hline Trust others & $0.000^{*}$ & 2.142 \\
\hline
\end{tabular}

Source: Survey of public attitudes towards conduct in public life 2003-04, BMRB Research.

Note: $*=\mathrm{p}<0.05$ 
Table 3 Results of modified logistic regression model for predictors of trust in MPs to tell the truth

\begin{tabular}{|l|l|l|l|l|l|}
\hline & $\begin{array}{l}\text { Regression } \\
\text { coefficients }\end{array}$ & Significance & $\begin{array}{l}\text { Odds } \\
\text { ratio }\end{array}$ & \multicolumn{2}{|l|}{$\begin{array}{l}\text { 95\% confidence } \\
\text { interval for odds ratio }\end{array}$} \\
\hline $\begin{array}{l}\text { Can influence } \\
\text { decisions: disagree }\end{array}$ & 0.642 & 0.000 & 1.900 & 1.401 & 2.577 \\
\hline $\begin{array}{l}\text { Can influence } \\
\text { decisions: strongly } \\
\text { disagree }\end{array}$ & 0.925 & 0.000 & 2.522 & 1.669 & 3.810 \\
\hline Trust others & 0.687 & 0.000 & 1.988 & 1.502 & 2.632 \\
\hline Constant & 0.052 & 0.683 & 1.053 & & \\
\hline \multicolumn{6}{|l|}{ Hosmer and Lemeshow Test Sig. $=0.825$} \\
\hline
\end{tabular}

Source: Survey of public attitudes towards conduct in public life 2003-04, BMRB Research. 